\title{
ANALISIS SURVIVAL PADA PENYAKIT GINJAL KRONIK DENGAN KOMORBIDITAS DIABETES MELITUS DENGAN MENGGUNAKAN COX REGRESSION
}

\author{
Nova Muhani ${ }^{*}$, Nurhalina Sari $^{*}$
}

\begin{abstract}
ABSTRAK
Penyakit ginjal kronis (PGK) merupakan masalah kesehatan masyarakat global dengan prevalensi dan insidens gagal ginjal yang meningkat, prognosis yang buruk dan biaya yang tinggi. PGK merupakan penyebab kematian. Secara global, penyebab PGK terbesar adalah komorbiditas dengan diabetes mellitus. Berdasarkan survei pendahuluan di unit hemodialisis dari tahun 2014-2017 masing-masing 165,172,238,306 kasus menunjukkan adanya peningkatan jumlah pasien baru dengan diagnosis PGK yang harus menjalani hemodialisis. Semakin meningkatnya pasien baru PGK di RSUDAM Bandar Lampung. Tujuan penelitian mengetahui satatus demografi (umur, jenis kelamin,) dan lama ketahanan hidup pasien PGK yang menjalani hemodialisis berdasarkan komorbiditas diabetes melitus, luaranya mengetaui probabilitas dan besaran risiko kematian PGK.

Desain kohort retrospektif, sampel sebesar 249 responden. Penelitian menggunakan data dari laporan harian unit hemodialisis dan rekam medis Analisis yang digunakan analisis survival. Sebanyak 249 responden bahwa terjadi kematian (Event) sebesar 46\%, terdapat $27,3 \%$ pasien PGK dengan Komorbiditas Diabetes Melitus. Responden hemodialisa berdasrkan jenis kelamin presentasinya tidak jauh berbeda antara laki-laki $(51 \%)$ dan perempuan (49\%). Hasil uji statistik diperoleh nilai-p $=0.001$. Dengan $a=0,05,(R R=1,9)$.
\end{abstract}

Kata Kunci : Penyakit Ginjal Kronis, Diabetes Melitus, Kohort Retrospektif

\section{ABSTRACT}

Chronic kidney disease (CKD) is a global public health problem with an increased prevalence and incidence of kidney failure, poor prognosis and high costs. CKD is a cause of death. Globally, the biggest cause of CKD is comorbidity with diabetes mellitus. Based on preliminary surveys in the hemodialysis unit from 2014-2017 each 165,172,238,306 cases showed an increase in the number of new patients with a diagnosis of CKD who had to undergo hemodialysis. The increasing number of new PGK patients in Bandar Lampung Hospital. The purpose of this study was to determine the demographic status (age, sex, ) and length of survival of patients with CKD undergoing hemodialysis based on comorbidity of diabetes mellitus, beyond knowing the probability and magnitude of the risk of CKD death. Retrospective cohort design, a sample of 249 respondents. The study used data from the daily report of the hemodialysis unit and medical records. The analysis used survival analysis. As many as 249 respondents that died (Event) by $46 \%$, there were $27.3 \%$ of CKD patients with comorbidities of Diabetes Mellitus. Hemodialysis respondents based on sex did not differ much between men (51\%) and women (49\%). Statistical test results obtained $p$-value $=0.001$. With $a=0.05,(R R=1.9)$.

Keyword : Chronic Kidney Disease, Diabetes Mellitus, Retrospective Cohort

\section{PENDAHULUAN}

Dewasa ini penyakit tidak menular (PTM) menjadi menjadi masalah kesehatan di berbagai belahan dunia. Peningkatan kasus PTM ini secara tidak langsung merupakan akibat adanya perubahan gaya hidup yang pasif, mengkonsumsi makanan yang banyak mengandung lemak, kolesterol, kebiasaan merokok, dan tingkat stress yang tinggi. Salah satu PTM yang menjadi masalah kesehatan adalah penyakit ginjal kronik (PGK).

*. Fakultas Kesehatan Masyarakat Universitas Malahayati 
Penyakit ginjal kronis (PGK) merupakan masalah kesehatan masyarakat global dengan prevalensi dan insidens gagal ginjal yang meningkat, prognosis yang buruk dan biaya yang tinggi. PGK merupakan penyebab kematian peringkat ke-27 di dunia tahun 1990 dan meningkat menjadi urutan ke-18 pada tahun 2010 . Sedangkan di Indonesia, perawatan penyakit ginjal merupakan ranking kedua pembiayaan terbesar dari BPJS kesehatan setelah penyakit jantung. Prevalensi PGK meningkat seiring meningkatnya jumlah penduduk usia lanjut dan kejadian penyakit diabetes melitus serta hipertensi. Hasil systematic review dan metaanalysis yang dilakukan oleh Hill et al, 2016 dalam (Kemenkes, 2017) mendapatkan prevalensi global PGK sebesar 13,4\%. Di Amerika berdasarkan survei National Kidney and Urologic Diseases Information Clearinghouse prevalensi PGK meningkat hampir 600\% antara tahun 1980 dan 2009, yaitu dari 290 menjadi 1.738 kasus per satu juta penduduk. Dari survei tersebut didapat angka kematian PGK juga meningkat dari tahun 1980 sebesar 10.478 menjadi 90.118 kasus pada tahun 2009 (NKUDIC, 2012). Beberapa Negara maju seperti Jepang, Australia dan Inggris, penderita PGK dilaporkan berkisar antara 77-283 per satu juta penduduk. Penduduk Malaysia dengan populasi 18 juta, diperkirakan terdapat 1800 kasus baru gagal ginjal pertahunnya (Rubianto \& Suwitra, 2009 dalam Neliya, 2012).

Data Indonesia Renal Registry memperlihatkan peningkatan pasien hemodialisis di Indonesia Pasien baru yang menjalani hemodialisis dari tahun 2007 sebanyak 4977 pasien menjadi 21050 pasien pada tahun 2015. Meningkatnya jumlah penderita PGK berbanding lurus dengan peningkatan pasien yang perlu menjalani terapi hemodialisis. Namun kenyataannya angka kematian pasien PGK yang menjalani terapi hemodialisis masih tinggi. terutama pada 3 bulan sampai 1 tahun pertama sejak menjalani hemodialisis. Beberapa penelitian memperlihatkan angka kematian 1 tahun pertama yang bervariasi mulai $6,6 \%$ sampai $\quad 74 \% \quad$ (Ibrahim 2009) ${ }^{4}$.
Berdasarkan laporan Idonesia Renal Registry (IRR, 2015) kematian tertinggi terjadi pada 6-12 bulan pertama menjalani hemodilaisa yaitu sebesar $33 \%$, sedangkan menurut penelitian Umami (2012) didapatkan angka kematian 3 bulan pertama pasien PGK yang menjalani hemodialisis sebesar $31,7 \%$.

Secara global, penyebab PGK terbesar adalah komorbiditas dengan diabetes mellitus (IRR, 2015). Pasien PGK dengan komordibitas diabetes militus dilaporkan meningkat dalam kurun waktu 15 tahun (Seok et al, 2010). Peningkatan jumlah pasien PGK dengan komordibitas diabetes militus yaitu $15,5 \%$ pada periode tahun 1988 1994 menjadi 19,3\% pada periode tahun 2005-2010 (Goldfarb-Rumyantzev and Rout, 2010).

RSUDAM merupakan rumah sakit pemerintah yang melaksanakan pelayanan hemodialisis di Provinsi Lampung. Berdasarkan survei pendahuluan di unit hemodialisis dari tahun 2014-2017 masing-masing $165,172,238,306$ kasus menunjukkan adanya peningkatan jumlah pasien baru dengan diagnosis PGK yang harus menjalani hemodialisis. Semakin meningkatnya pasien baru PGK di RSUDAM Bandar Lampung yang menjalani hemodialisis dari tahun ke tahun dan besarnya resiko kematian pasien PGK yang menjalani hemodialisis dengan komordibitas diabetes mellitus serta tingginya biaya kesehatan yang harus dikeluarkan.

Penyakit Ginjal Kronis (PGK) merupakan suatu proses patofisiologi dengan etiologi yang beragam, mengakibatkan penurunan fungsi ginjal yang progresif, dan pada umumnya berakhir dengan gagal gijal. Penyakit ginjal kronis adalah suatu keadaan klinis yang ditandai dengan penurunan fungsi ginjal yang ireversible, pada suatu derajat yang memerlukan terapi pengganti ginjal yang tetap, berupa dialisis atau transplantasi ginjal dengan mempunyai kriteria, berupa kelainan structural atau fungsional, dengan atau tanpa penurunan laju filtrasi glomerulus (LFG) kurang dari $60 \mathrm{ml} / \mathrm{menit} / 1,73 \mathrm{~m} 2$ ), dengan manifestasi: kelainan patologis atau terdapat tanda berdasarkan 
kelainan ginjal, termasuk kelainan dalam komposisi darah atau urin, atau kelainan dalam tes pencitraan (imaging tests) National Kidney Fondation - Kidney Disease Outcame Quality Invintative (NKF-KDOQI, 2002) dalam Herman 2016. Hemodialisis adalah pembuangan limbah metabolic dan kelebihan cairan dari tubuh melalui cairan dalam tubuh melalui darah. Prosedur termasuk pemompaan darah pasien yang telah diberi heparin melewati mesin ginjal buatan (dialyzer) dengan kecepatan 300-500 $\mathrm{mL} / \mathrm{min}$, sementara cairan dialisat secara berlawanan arah dengan kecepatan 500-800mL/min. darah dan dilaisat sendiri hanya dipisahkan oleh suatu membran semipermaeble (Singh dan Brwnner, 2005 dalam Junaidi, 2009).

Salah satu penyebab risiko kematian pasien PGK yang menjalani hemodialisis adalah komordibitas. Komordibitas yang paling umum ada pada pasien PGK yang menjalani hemodialisis adalah diabetes militus. Komordibitas Diabetes Mellitus Secara etiologi, diabetes mellitus merupakan penyakit yang menyebabkan kelainan ginjal sekunder. Penyakit diabetes mellitus yang menahun menyababkan komplikasi nefropati diabetik. Gejala awal komplokasi ini ditandai dengan dimuinya protein dalam urin (proteinnuria). Bila proteinuria terjadi sangat hebat maka penderita akan mengalami kekurangan protein dalam darah yang mengakibatkan timbulnya sembab di seluruh tubuh (sindrom nefrotik). Bila keadaan ini berlangsung lama tanpa penangan dengan baik maka akan menyebabkan gangguan ginjal dan akhirnya bila progretifitas LFG meningkat pada paseien PGK (Corwin, 2010 dalam Fatimah 2012).

Seseorang dengan penyakit PGK dengan komordibitas diabetes mellitus untuk terjadinya berbagai komplikasi baik secara akut maupun kronis. Komplikasi akut yang dapat terjadi antara lain merupakan hiperglekemis/ketoasidosis dan hipoglekimia akibat dari adanya gangguan control gula darah. Kondisi hyperglikemis akut menyebabkan terjadinya glukoneogensis. Glukoneosis adalah kondisi dimana menurunnya $\mathrm{pH}$ darah akibat timbulnya produk antara saat memproduksi asam amino, asam lemah dan benda keton sehingga menyebabkan terjadinya asidosis. Bila kondisi ini tidak ditangani dengan baik akan mengakibatkan koma dan kematian (Greene, 1993;Sue, 2006 dalam Fatimah, 2012).

Secara global, penyebab PGK terbesar adalah diabetes mellitus. Di Indonesia, sampai dengan tahun 2000, penyebab terbanyak adalah glomerulonefritis, namun beberapa tahun terakhir menjadi hipertensi berdasarkan data IRR. Namun belum dapat dipastikan apakah memang hipertensi merupakan penyebab PGK atau hipertensi akibat penyakit ginjal tahap akhir, karena data IRR didapatkan dari pasien hemodialisis yang sebagian merupakan pasien dengan penyakit ginjal tahap akhir. Beberapa penelitian terdahulu melaporkan bahwa diabetes militus merupakan salah satu faktor yang mempengaruhi ketahan hidup pasien PGK yang menjalani hemodialisis. Sebuah penelitian jangka panjang di Iran oleh Beladi-Mousavi, et.al (2012) untuk melihat perbedaan ketahanan hidup 1 sampai 15 tahun pasien PGK yang menjalani hemodialisis berdasarkan penyebab PGK karena diabetes militus. Pada penelitian ini, didapat bahwa ketahanan hidup pasien PGK dengan penyebab diabetes mellitus lebih tinggi dibandingkan pasien bukan penyebab diabetes mellitus dan tidak ada pasien dengan diabetes mellitus yang dapat bertahan hidup tidak lebih dari 10 tahun.

\section{METODE PENELITIAN}

Desain dalam penelitian ini menggunakan desain kohort retrospektif. Bisma (2015) ${ }^{13}$ menyatakan bahwa studi kohort disebut juga follow up atau studi prospektif, sebab kohort diikuti dalam suatu periode yang diamati perkembangannya, rancangan studi kohort dapat bersifat retrosfektif atau prospektif adalah jika paparanya terjadi sebelum peneliti memulai penelitianya. Pada rancangan ini data yang digunakan bersifat skunder.

Penelitian ini menggunakan data dari laporan harian unit hemodialisis dan rekam medis pasien baru yang menjalani hemodialisis di unit 
hemodialisi di Rumah Sakit Abdul Moeloek yang dimulai 01 Januari 2018 sampai 30 Juni 2018 yang diikuti sampai dengan 30 Juni 2019. Populasi dalam penelitian ini adalah pasien yang menjalani hemodialisis pada 01 Januari 2018 sampai 30 Juni 2018. Sampel dalam penelitian ini mempunyai kriteria yaitu pasien baru yang menjalani hemodialisis yang terhitung tanggal 01 Januari 2018 sampai 30 Juni 2018, dengan diagnosis utama penyakit ginjal kronik, usia lebih dari 18 tahun, mempunyai data riwayat menjalani hemodialisis, dan mempunyai hasil laboratorium fungsi ginjal (kreatin) pada awal menjalai hemodialisis. Sampel yang digunakan sebanyak 259 responden. Analisis yang digunakan analisis survival yaitu penggunaan kapplan meier dengan log rank serta permodelannya menggunakan regresi cox dengan asumsi proporsional hazard. Penggunakan kapplan meier dengan log rank untuk melihat probabilitas ketahanan hidup sedangkan regresi cox dimasukkan untuk mengestimasi Hazard Ratio (HR) menguji hipotesis dari HR dan melihat confident interval. Untuk dapat menggunakan multivariat dengan cox regression/cox proportional hazard, variabel-variabel dalam penelitian tersebut harus dilakukan uji global.

HASIL

Hasil Deskriptif

Status Hemodialisa

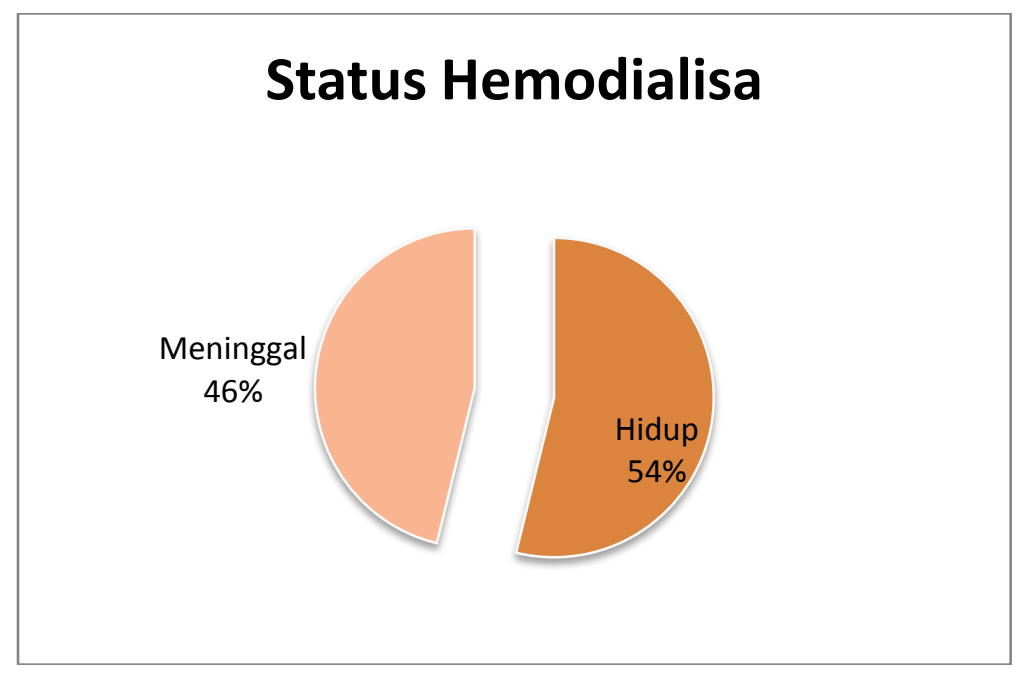

Gambar 1

Status hemodialisa

Dari gambar diatas, sampel yang diamati selama 12 bulan sebanyak 249 responden bahwa terjadi kematian (Event) sebesar $46 \%$ sedangkan yang hidup 54\% yaitu berkunjung setiap bulan dan yang mengalami drop out (Sensor), hal ini dapat dijelaskan bahwa kematian pada pasien PGK banyak terjadi pada 12 bulan pertama hal ini tidak jauh berbeda dengan laporan indonesia renal register yang menjelaskan bahwa kematian PGK pada bulan ke satu sampai kurang dari tiga hemodialisa sebesar $22 \%$, pada bulan ke tiga sampai ke enam $18 \%$ dan pada bulan ke enam sampai 12 bulan $33 \%$ kalau kita jumlahkan maka kematian pasien PGK yang menjalani hemodialisa sampai bulan ke 12 sebesar $63 \%$. 


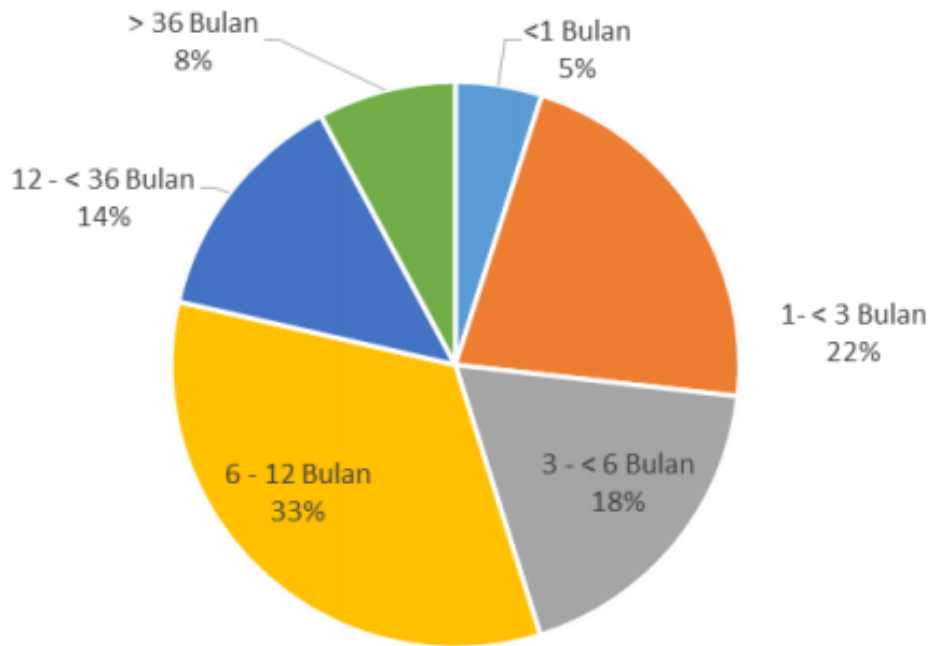

Gambar 2

Pasien Meninggal Berdasarkan Lama Hidup.

Sumber: Indonesia Renal Registry (IRR), 2016

Komorbiditas PGK dengan Diabetes Melitus

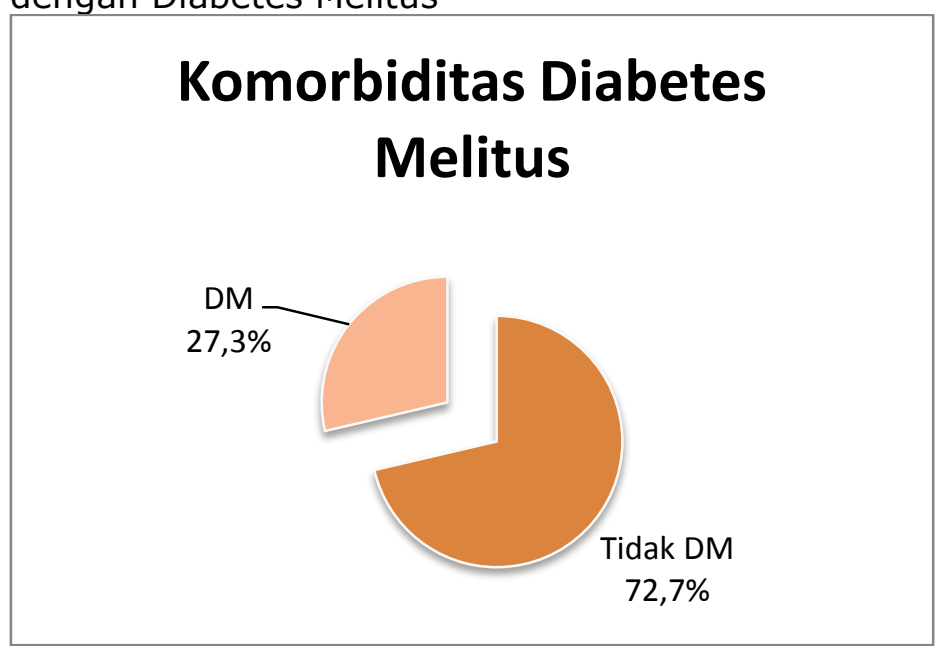

Gambar 3

Komorbiditas Diabetes Melitus

Pada tabel diatas menjelaskan bahwa dari 249 responden terdapat 27,3\% pasien PGK dengan Komorbiditas Diabetes Melitus, hasil ini tidak jauh berbeda dengan laporan IRR bahwa Penyakit penyerta pasien hemodialisis pada tahun 2015 dapat dilihat pada diagram, hipertensi masih merupakan penyakit penyerta terbanyak, dan disusul oleh diabetes melitus sebesar $22 \%$. 


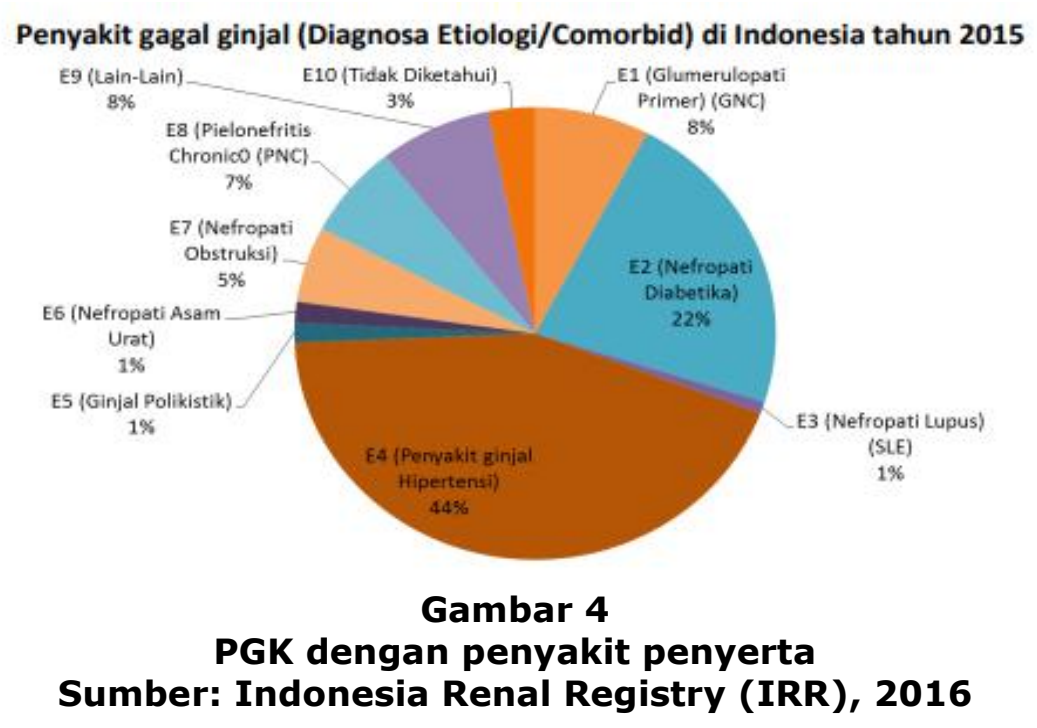

Berdasrkan jenis kelamin

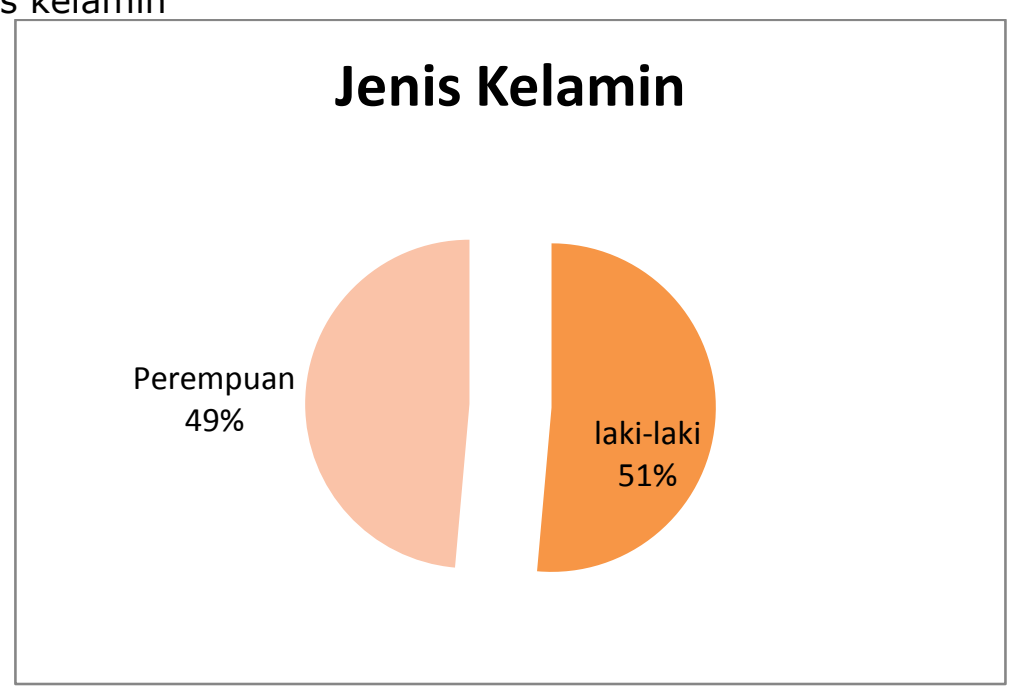

\section{Gambar 5 Jenis Kelamin}

Berdasarkan tabel diatas bahwa responden hemodialisa berdasrkan jenis kelamin presentasinya tidak jauh berbeda antara laki-laki (51\%) dan perempuan (49\%). Hal ini juga sama dengan IRR 2016 bahwa terdapat 54,7\% pasien Hemodialisis berjenis kelamin laki-laki sedangkan perempuan $45,3 \%$.

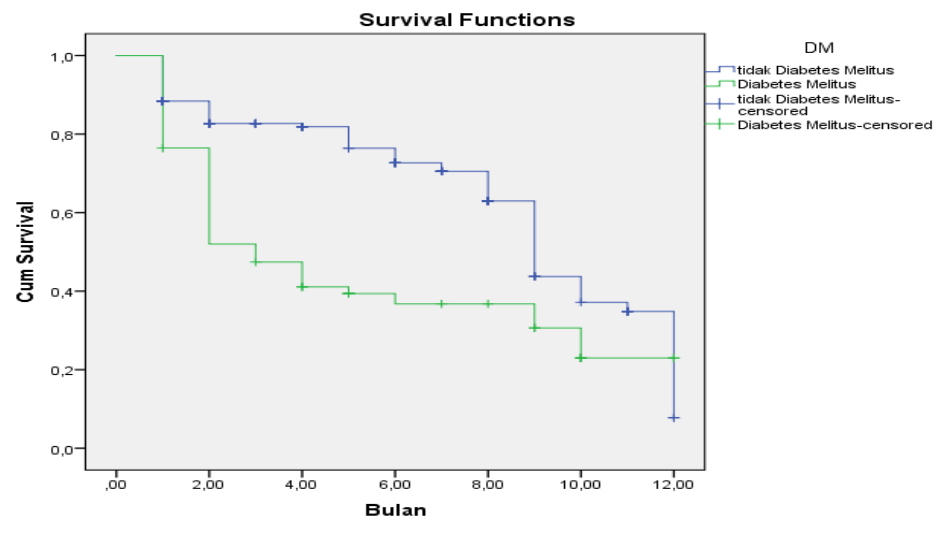

Gambar 6

Survival Function pasisn hemodialisis dengan komorbiditas diabetes melitus

186 Jurnal Dunia Kesmas Volume 8. Nomor 4. Oktober 2019 (Edisi Khusus) 
Grafik di atas memperlihatkan bahwa kelompok tidak diabetes melitus memiliki survival rate yang lebih tinggi dibandingkan kelompok yang mengalami diabetes. Plotting garis fungsi survival pada grafik Kaplan Meier digambarkan setiap waktu sesuai kejadian event. Jumlah sensor, pada kelompok diabetes melitus dan tidak diabetes melitus juga tergambar. Pada grafik tersebut tampak sensor terdapat pada kedua kelompok. hasil uji perbedaan survival antara kelompok diabetes melitus dan tidak diabetes melitus dengan menggunakan metode Log Rank. Hasil uji statistik diperoleh nilai- $p=0.001$. Dengan $a=0,05$, Kelompok tidak diabetes melitus memiliki ketahanan hidup 1,9 kali lebih tinggi dibandingkan kelompok diabetes melitus Kelompok tidak diabetes melitus memiliki waktu yang lebih lama untuk hidup dibandingkan dengan kelompok diabetes melitus. Penelitian ini sejalan dengan penelitian yang dilakukan oleh Fatimah, Tantri (2012) bahwa pasien PGK yang menjalani hemodialisis dengan komorbiditas diabetes mellitus memiliki risiko untuk meninggal 1.75 kali lebih cepat dibandingkan dengan pasien komorbiditas bukan diabetes mellitus. Penelitian Doni, Yulianto, dkk (2017) menjelaskan bahawa Ketahanan hidup pasien dengan riwayat Diabetes Melitus lebih rendah daripada pasien yang tidak memiliki riwayat penyakit dengan nila log rang $(0,035)$. Hasil penelitian ekantari, dkk (2012) menunjukkan ada hubungan antara diabetes mellitus tipe II $\quad(p=0,046 ; \quad O R=2,852 ;)$, berbeda dengan penelitian $A$. Chandrashekar, $S$. Ramakrishnan, and D. Rangarajan (2014) tidak ada perbedaan yang signifikan pasien yang melakukan hemodialisis dengan penyakit penyerta diabetes dan tidak diabetes (Relative Risk = 1.109; 95\% CI $=0.49-2.48, P=$ 0.803 ) sama hal nya dengan penelitian Windari, ditha (2011) Ketahanan hidup 1 tahun pasien PGK dengan etiologi DM adalah $47,7 \%$ sedangkan yang dengan etiologi non DM sebesar $62 \%$. Hasil uji statistik denganKaplan-Meier Survival Analysis dan uji Log Rank didapatkan nilai $p=0,136>a=0,05$ (tidak bermakna).

\section{SIMPULAN}

Sebanyak 249 responden bahwa terjadi kematian (Event) sebesar $46 \%$ sedangkan yang hidup $54 \%$ yaitu berkunjung setiap bulan dan yang mengalami drop out (Sensor). terdapat $27,3 \%$ pasien PGK dengan Komorbiditas Diabetes Melitus. Responden hemodialisa berdasrkan jenis kelamin presentasinya tidak jauh berbeda antara laki-laki (51\%) dan perempuan (49\%). hasil uji perbedaan survival antara kelompok diabetes melitus dan tidak diabetes melitus dengan menggunakan metode Log Rank. Hasil uji statistik diperoleh nilai- $p=0.001$. Dengan $a=0,05$, Kelompok tidak diabetes melitus memiliki ketahanan hidup 1,9 kali lebih tinggi dibandingkan kelompok diabetes melitus Kelompok tidak diabetes melitus memiliki waktu yang lebih lama untuk hidup dibandingkan dengan kelompok diabetes melitus.

\section{SARAN}

Bagi pasien gagal ginjal kronik yang sudah memiliki penyakit penyerta diabetes hendaknya lebih menjaga kesehatan, misalnya dengan diet protein, melakukan konsultasi kepada tenaga medis, dan sering melakukan check up untuk mengontrol kadar gula dalam darah memberikan edukasi kepada pasien maupun keluarga pasien di klinik hemodialisis mengenai faktor risiko dari penyakit diabetes mellitus, yang dapat menyebabkan kematian pada pasien gagal ginjal kronik.

\section{DAFTAR PUSTAKA}

(NKUDIC, 2012).kidney disease statistic for united state. Cited: 03 Maret 2018, File From :

http://kidney.niddk.gov/kudiseas es/pubs/kustats/\#4

Neliya, Susti (2012). Hubungan Pengetahuan tentang asupan cairan dengan dan cara pengendlian asupan cairan terhadap penambahan berat badan, tesis:pekanbaru:FIK UNRI

Anees M \& Ibrahim M. (2009, Desembaer) Anemia dan hypoalbumenia at initation of hemodyalysis as risk factor for Survival of dialysis patient, Vol. 
19(12)776-80 Journal of The College and physician Surgeon Pakistan. Cited: 03 Maret 2018, File From : http://www.ncbi.nml.nih.gov/pub med/20042156

Belhttp://content.ebsadi-Mousevi, et al. 2012. Long Term Survival of Patiens with End Stage Renal Disease on Meintenance Hemodyalisis: A Multicenter Study in Iran, Vol.6(6)452-456 Iranian Journal of Kidney Disese. Cited: 01 Maret 2018, File from cohost.com

Chandrashekar, A., Ramakrishnan, S., \& Rangarajan, D. (2014). Survival analysis of patients on maintenance hemodialysis. Indian journal of nephrology, 24(4), 206-213. doi:10.4103/09714065.132985. Cited: 05 September 2019, File From: https://www.ncbi.nlm.nih.gov/pm c/articles/PMC4119332/

Dony Yulianto, Hari Basuki Notobroto, Widodo (2017) analisis ketahanan hidup pasien penyakit ginjal kronis dengan hemodialisis di RSUD dr. Soetomo surabaya, Jurnal Manajemen Kesehatan Yayasan RS Dr. Soetomo, Vol. 3 No. 1, April 2017 : 99-122. Cited: 05 September 2019, File From: https://media.neliti.com/media/p ublications/258424-analisisketahanan-hidup-pasienpenyakit-a82c8244.pdf

Ekantari, Firiana (2011). Hubungan antara lama hemodialisis dan faktor komorbiditas dengan kematian pasien gagal ginjal kronik di RSUD dr. Moewardi. Skripsi: Universitas Muhammadiyah surakarta. Cited: 05 September 2019, File From: http://eprints.ums.ac.id/20533/1 8/JURNAL PUBLIKASI.pdf

Fatimah, Tantri (2012) $)^{12}$ ketahanan hidup pasien ginjal kronik yang menjalani hemodialisis berdasarkan komorditas diabetes melitus di RSUD Arifin Achmad Pekanbaru tahun 2011- 2012. Jakarta: Tesis. FKMUI.

Goldfarb-Rumyantzev and Rout, (2010). Caracteristic of erderly Patients with Diabetes and End-Stage Renal Disease, Vol.23(2)185-190. Seminar in Dialysis. Cited: 01 Maret 2018, File from http://content.ebscohost.com

Herman, I. 2016. Hubungan Lama Hemodialisis dengan Fungsi Kognitif Pasien Penyakit Ginjal Kronis yang Menjalani Hemodialisis di RSUD Abdul Moeloek Bandar Lampung. Skripsi Fakultas Kedokteran. Universitas Lampung.

Idonesia Renal Registry (IRR, 2015) 8th Report Of Indonesian Renal Registry, Cited: 03 Maret 2018, File From: https://www.indonesianrenalregis try.org/data/INDONESIAN\%20RE NAL\%20REGISTRY\%202015.pdf

Junaidi, M. Ade. (2009). Status Indeks Massa Tubuh Pasien PGK yang menjalani Hemodialisis di RSCM pada bulan Februari 2009 dan Korelasinya dengan lama menjalani Hemodialisis. Jakarta: Tesis. FKUI.

Kemenkes, (2017) Pusat Data Dan Informasi Kementerian Kesehatan RI. Cited: 01 Okt 2018, from: file:///C:/Users/Hp/Downloads/inf odatin\%20ginjal\%202017\%20(1) .pdf

Murti, Bhisma (2015) Prinsip Dan Metode Riset Epidemiologi. Yogyakarta: Gajah madaUnivesity Press.

Seok et al, (2010). Comparison of patienes starting hemodialisis with those underwent hemodialisis 15 years at the same dialysis center in korean $\mathrm{J}$ intern Med. Cited: 03 Maret 2018, File From:

http://www.ncbi.nlm.nih.gov/pmc Larticles/PMC2880693/pdf/kjim25-188.pdf 
Umami,Vidia (2012). Pengembangan Model Prediksi Mortalitas 3 Bulan Pertama Pada Pasien Penyakit Ginjal Kronik Yang Menjalani Hemodialisis Akut. Jakarta:Tesis.FKUI

Windari, dita Putri (2011). Ketahanan hidup pasien penyakit ginjal kronik akibat diabetes dan non diabetes yang menjalani hemodialisis rutin di rsud $\mathrm{dr}$. Moewardi Surakarta. Skripsi Universitas Muhammadiyah surakarta. Cited: 05 September 2019, File From: http://eprints.ums.ac.id/14882/1/ Halaman Depan CoverAbstrak .pdf 